LOVE FOR SALE 
A VOLUME IN THE NIU SERIES IN

Slavic, East European, and Eurasian Studies

Edited by Christine D. Worobec

For a list of books in the series, visit our website at cornellpress.cornell.edu. 


\section{LOVE FOR SALE}

REPRESENTING PROSTITUTION

IN IMPERIAL RUSSIA

\section{Colleen Lucey}


Copyright (C) 2021 by Cornell University

All rights reserved. Except for brief quotations in a review, this book, or parts thereof, must not be reproduced in any form without permission in writing from the publisher. For information, address Cornell University Press, Sage House, 512 East State Street, Ithaca, New York 14850. Visit our website at cornellpress.cornell.edu.

First published 2021 by Cornell University Press

Library of Congress Cataloging-in-Publication Data

Librarians: A CIP catalog record for this book is available from the Library of Congress.

ISBN 978-1-5017-5886-7 (hardcover)

ISBN 978-1-5017-5888-1 (pdf)

ISBN 978-1-5017-5887-4 (epub)

Jacket illustration: Ivan Kramskoi, Neizvestnaia (Portrait of an Unknown Woman), 1883. Oil on canvas, $75.5 \times 99 \mathrm{~cm}$.

State Tretyakov Gallery, Moscow. 
For Ben 
